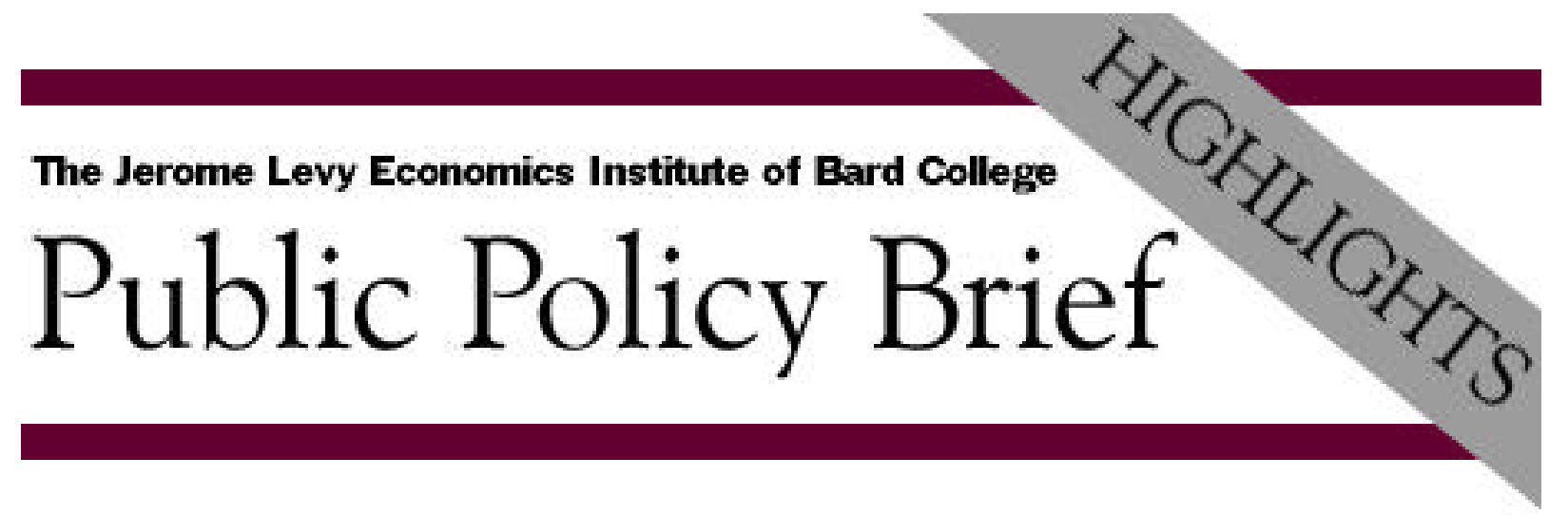

No. 44A, September 1998

\title{
The Asian Disease: Plausible Diagnoses, Possible Remedies
}

\section{Martin Mayer}

The Asian crisis is a textbook case of the "financial instability hypothesis" first expressed in 1966 by the late Hyman Minsky. It began with what Minsky called

the economics of euphoria: . . . The confident expectation of a steady stream of prosperity gross profits [produces a] willingness ... to take what would have been considered in earlier times undesirable chances in order to finance the acquisition of additional capital goods. ... Those that supply financial resources live in the same expectational climate as those that demand them. ... An essential aspect of a euphoric economy is the construction of liability structures which imply payments that are closely articulated ... to cash flows due to income production. ... Withdrawals on the supply side of financial markets may force demanding units that were under no special strain and were not directly affected by financial stringencies to look for new financing connections. An initial disturbance can cumulate through such third-party or innocent-party bystanders. . . . Financial instability occurs whenever a large number of units resort to extraordinary sources for cash. (Minsky 1972, 110?105)

In the economics of euphoria, lenders eagerly supply funds for the acquisition of capital assets that will not yield the borrowers sufficient returns to service the loans. Thus the borrowers become dependent on the willingness of lenders to keep increasing their loans--a situation Minsky described as "Ponzi finance." Any interference with this cheerful articulation of borrower and lender will push borrowers--and then lenders--into insolvency. In Minsky's terms, the enormous capital inflows drawn by the "Asian miracle" led inevitably to financial instability. What was new in this crisis was the predominance of interbank lending as the source of trouble. Confident that governments would not permit their banking systems to default, foreign banks often failed even to seek information about how their interbank loans would be paid back and permitted their money to be used to make up shortfalls in repayment by bankrupt borrowers. Because these interbank loans were short term and denominated in the currency of the lender rather than the currency earned by the borrower's debtor, the loss of articulation produced both a banking and a currency crisis. The Asian tragedy demonstrates the need for improved regulation of cross-border interbank lending, improved accounting for both borrowers and lenders, and some separation of the close links between governments and their banking sectors.

Minsky's "hypothesis" was proposed to explain instability in a large, insulated, developed economy. Despite its intuitive appeal, it was not widely accepted among financial economists (Charles Kindleberger [1978] being a notable exception) because, they said, they could not find historical illustrations to fit the theory. The financial economist's machine runs smoothly in the best of all possible worlds. The capital asset pricing model 
developed and refined in the universities since the 1960s explains values always and everywhere, and diversification minimizes the effects of asymmetric shocks. Since all the information is already in the prices, all decisions are rational and optimize the total performance of the universe of players. The only thing that can make trouble in the financial economist's world is the exogenous shock that affects everyone (war, oil prices) or government error (fiscal imbalance, monetary policy).

But Asia presents a cumulation of apparently rational decisions that produced disastrous results--precisely as Minsky predicted. No clearer expression of economic euphoria can be imagined than the words "Asian miracle." Budgets were apparently balanced (ignoring quasi-fiscal deficits in the banking system and the state-owned enterprises), current account balances were favorable or explicable as the mirror image of capital inflows. Currencies were stable vis-à-vis the dollar for years, despite the divergence of local and American interest rates, and nobody cared that governments and central banks intervened in the forward markets (increasingly, with the passage of time, on a highly leveraged derivative chassis) to pay out the obvious profits to arbitrageurs who borrowed in the dollar market and lent in the local market.

The whirlpool that drowned the financial voyagers in Asia was the interbank market, and the best short-term program for reducing the chance of new crises and minimizing their severity would be a system for identifying and fencing off the use of interbank borrowing. This is where the worst of the moral hazard lies. Because governments and central banks will ultimately stand behind their failing banks, bankers are lax about loans to other banks. Interbank dealings are often accomplished through "blind brokers," so that neither lender nor borrower knows the identity of its counterparty until the trade is finished. There are some controls. Most banks have a limit on how much in overnight Fed Funds they will "sell" to any given bank, but they have no way to know what that bank may be buying from others in the market or its total interbank indebtedness. Banco Ambrosiano Holdings, an essentially unregulated Luxembourg offshoot of an Italian bank, was able to borrow half a billion dollars from 250 international banks in 1983. "Clearly," Robert E. Litan and Richard J. Herring note, "these interbank placements were not made on the basis of rigorous credit analysis, because even now, with the benefit of a decade of hindsight, little is known about what BAH actually did with the money" (1994, 101).

The international community needs some sort of registry that would call attention to any bank's or national banking system's continuing increase in short-term borrowings from financial firms. Because most of these borrowings take the form of repurchase agreements for investments that exist only as book-entry items at a central bank, there is in fact a record that can be consulted. Unfortunately, each bank's end-of-day position is created in a maelstrom of trading that runs 24 hours every business day. Securities houses as well as banks are continuous participants in the market, and the net position of the banks at the close of day may reflect the requirements of securities houses, not banks. Moreover, bank treasurers who know they will need to borrow money tonight may well spend the first hours of the day selling it to see if they can push down their price, while treasurers who know they will have money on offer at the end of the day may spend much of their time buying in hopes of helping a trend they can profitably ride. Choosing a time when the music stops and everybody has to announce his interbank position will be difficult (though not impossible--American banks do have to get their required reserves into the Fed before the FedWire closes). And even those who most value transparency in financial matters will see the need for limiting access to this information: the efficiency of a banking system would not be enhanced by daily speculations over why some bank shows an anomalous change in its net interbank position. Still, just as the CHIPS computer at the New York Clearing House has a program that flags any bank's promised payments to the clearing far in excess of its contemporaneous receipts of promises to pay by other banks, some international institution could monitor large anomalous short-term borrowings by banks.

Arrangements to police interbank lending will be meaningless, however, unless the central banks and the banking regulators can get a handle on the generation of over-the-counter derivatives. Action on this front is long overdue. In mid 1997, according to the International Swap Dealers Association, the "notional value" of outstanding OTC contracts was about \$29 trillion (Tait 1998, 15). Notional value is considered a deceptive figure, because the derivative contract pays off or imposes costs according to the change in relative values of the instruments. A swap that trades interest payments on $\$ 1$ million dollars for some multiple of interest payments on 140 million yen places the parties at risk for much less than the million dollars of notional value. In the Asian crisis, however, because currency values and interest rates changed so rapidly, notional value 
turned out to be a number of considerable significance. A lawsuit by J. P. Morgan against a Korean counterparty indicates that the loss on a notional \$250 million leveraged currency swap had turned out to be a real \$189 million. Andrew Sheng, deputy chief executive of the Hong Kong Monetary Authority, had stated the problem the year before:

Some analysts argue that regulators should not be concerned with the gross value of derivatives, but only with the net replacement cost of derivatives trading. Net replacement costs could be quite low when the volatility of markets is low. But in unusual markets ... underlying markets can dry up and bid-ask spreads can widen considerably, resulting in many derivatives models not being able to price their derivatives correctly and placing their buyers and sellers in a high-risk environment. ... The current lack of transparency in derivatives trading means that many regulators are not aware of the true size of the risks being assumed by their banking systems. $(1996,178)$

Not the least of the reasons why the Asian currencies and markets fell so far so fast was the fact that nobody knew the extent of the contingent liabilities the banks and their counterparties had assumed in OTC derivatives contracts. The mathematical models of price movements and covariance underlying the construction of these liabilities simply collapsed as actual prices departed so far from "normal" probabilities. One would have expected the banks involved to play down the theoretical justifications for their mistakes and to seek better information and judgment. But a participant in a conference about derivatives at the Stern School at New York University, held soon after the Asian disaster, reported that the topic was not limitations on the complexity and opacity of derivative instruments, but rather their extension and refinement to cover even more contingencies beyond the parameters of the bell curve.

Actually, the solution to the derivatives dilemma is easy to find and easy to administer. The supposed risk-reduction purpose of derivatives can also be achieved by the use of exchange-traded and publicly priced futures and options contracts. This solution was proposed in 1994 by David Folkerts-Landau, then director of capital markets research at the International Monetary Fund, and Alfred Steinherr of the European Investment Bank. Their essay on the subject won the annual American Express Bank Review brilliancy prize. They wrote:

\author{
Not the least of the reasons \\ why the Asian currencies \\ and markets fell so far so fast \\ was the fact that nobody \\ knew the extent of the \\ contingent liabilities the \\ banks and their counter- \\ parties had assumed in OTC \\ derivatives contracts.
}

By increasing capital requirements for OTC derivative positions and thereby making them more costly relative to exchange/clearing house positions, it is possible to induce a shift towards the exchange/clearing house market structure. In terms of the various risks generated by OTC derivative activity, credit risk would be reduced by marking to market with margining, transparency of price discovery would increase, liquidity risk would be reduced by the fungibility of contracts, legal risks would be eliminated under existing laws, and operational risk would be reduced. (Folkerts-Landau and Steinherr 1994, 2?3)

What is actually happening, unfortunately, is that the central banks, the Bank for International Settlements, and the private-sector Group of Thirty are all looking for ways to reduce the capital that banks must allocate against their derivatives positions. Chairman Greenspan has said that "stress tests, which address the implications of extreme scenarios," will take care of the garbage-in problem the mathematical models now cannot solve. "[A]s credit risk analysis and risk management processes in general become more sophisticated," he added, "the framework for regulation and supervision, including the framework for capital charges, will need to adapt to, and take advantage of, evolving risk management practices" (Greenspan 1998, 8).

Central banks are the source of the moral hazard in cross-border banking. Concerned by the diminishing franchise value of a banking charter, they are virtually without exception eager to help banks try new things that promise higher rewards. To the extent that these rewards are bought by greater risks, they are not real. "[T]he compensation for greater risk," as Joseph Schumpeter wrote in 1911, "is only apparently a greater return; it has to be multiplied by a probability coefficient whereby its real value is again reduced--and indeed by exactly the 
amount of the surplus. Anyone who simply consumes this surplus will atone for it in the course of events" (Schumpeter 1934, 33). But like the money illusion at the beginning of inflation, profits from taking positions in derivatives look good early on. It is because the large banks know that the central banks will take care of their liabilities, especially in an international context, that they engage in risky behavior. The violence of the break when trouble occurs is because the market loses faith in the central banks. The recommended remedy on all sides is better accounting practice for all, more transparency and market discipline. But central banks want to maintain their discretion to use charitable accounting procedures that will give their banks a bella figura , they believe in bank secrecy, and their view of market discipline is that of McKinsey \& Co.'s Lowell Bryan: "so-called market discipline is simply another name for bank panic" (1991, 40).

When the crunch comes, to quote Sheng once more, "There is an inherent conflict between monetary policy and bank supervision policy. At a time when the central bank is concerned with maintaining a stable currency, there may be a need to rescue banks, which creates a quasi-fiscal burden. Monetary creation through lending to rescue banks negates the ability of tight monetary policy to combat inflation or capital flight" $(1996,179)$. The difficulty, as Ricardo Hausman points out, is that banks are both the operators of the payments mechanism and financial intermediaries (Claessens and Gooptu 1993, 31). Quite apart from the question of their putative independence from the government, the central banks cannot afford to lose the services of the banks in the payments system and must therefore protect them from their own errors as financial intermediaries.

The Financial Times can see no prophylaxis against the Asian disease except the complete removal of the banks from development finance:

If there is one lesson from the experience of the last two decades, it is that banks are disastrous vehicles for large-scale capital flows across frontiers. The short-term money they provide is unsuitable for finance of long-term investment; the expectation of help from their home authorities makes them willing to take on excessive risk; and their attempts to take their money out impose intolerable pressure on exchange rates of the capital importers. (Financial Times 1998)

But banks that are not also part of the payments system that must be protected from systemic risk will not carry these diseases, and the good news is that technology will soon rescue us from the dilemma. Banks as we have known them are no longer needed in the payments system, and deposits are no longer a major part of the funding of a large bank. As technology lowers the cost of processing payments, the risk-free "narrow bank" that invests exclusively in government securities becomes practical. Real time gross settlement, which will be achieved in Europe by 2001, virtually eliminates the uncertainties of missed payments. The creation of the Euro largely destroys monetary policy as a tool of governance in the European Union. The credit card companies, the data processors, and the ATM networks have sabotaged the demand-for-money function that informs the theory of central banking. To the extent that the banks themselves wish to be brokers rather than holders of assets, the danger of a "run" is greatly diminished. From the experience of Drexel in 1990, we know that very large securities firms, very significant participants in international clearing operations, can be allowed to fail without systemic consequences.

Looking ahead, the plan should be to separate depository institutions and payments providers from the wholesale financial institutions that would be authorized in all versions of pending American banking legislation. Financial intermediaries reporting their assets at market prices, financed by the market and relying on their own rather than the government's safety net, will be better partners for the developing world and less likely to break apart with Minskian fragility.

\section{References}

Bryan, Lowell L. 1991. Bankrupt . New York: HarperBusiness.

Claessens, Stijn, and Sudarchan Gooptu. 1993. Portfolio Investment in Developing Countries . World Bank Discussion Paper 228. Washington, D.C.: World Bank. 
Financial Times . 1998. "The Trouble with Global Finance." March 6.

Folkerts-Landau, David, and Alfred Steinherr. 1994. "Derivatives: Taming the Beast." The Amex Bank Review , November 16, 2 ?3.

Greenspan, Alan. 1998. Remarks before the Annual Financial Markets Conference of the Federal Reserve Bank of Atlanta, February 27.

Herring, Richard J., and Robert E. Litan. 1994. Financial Regulation in the Global Economy . Washington, D.C.: Brookings Institution.

Kindleberger, Charles. 1978. Manias, Panics and Crashes . New York: Basic Books.

Minsky, Hyman P. 1972. "Financial Instability Revisited." In Reappraisal of the Federal Reserve Discount Mechanism . Washington, D.C.: Federal Reserve System.

Schumpeter, Joseph. 1934. The Theory of Economic Development , translated by Redvers Opie. Cambridge, Mass.: Harvard University Press.

Sheng, Andrew. 1996. Bank Restructuring: Lessons from the 1980s . Washington, D.C.: World Bank.

Tait, Nikki. 1998. "Uncertain Futures Ahead." Financial Times , March 23, 15.

\section{About the Author}

Martin Mayer, currently a guest scholar at The Brookings Institution, has been writing about financial subjects for four decades. His books on banking and business include Wall Street: Men and Money (1955), Madison Avenue, USA (1958), The Bankers (1975), The Fate of the Dollar (1980), The Money Bazaars (1984), The Greatest Ever Bank Robbery (1990), Stealing the Market (1992), Nightmare on Wall Street (1993), and The Bankers: The Next Generation (1997). He has also written books on such subjects as the legal profession, diplomacy, education, and news gathering organizations. From 1987 to 1989 he wrote a twice-monthly front-page column in American Banker and is also a music critic. Mayer served on the President's Panel on Educational Research and Development in the Kennedy and Johnson administrations and was a member of the National Commission on Housing for Ronald Reagan. He received a B.A. from Harvard College.

\section{The full text of this paper is published as Levy Institute Public Policy Brief No. 44.}

The Jerome Levy Economics Institute is publishing this proposal with the conviction that it represents a constructive and positive contribution to the discussions and debates on the relevant policy issues. Neither the Institute's Board of Governors nor its Board of Advisors necessarily endorses the proposal.

(C) Copyright 1998 by The Jerome Levy Economics Institute.

ISSN 1094-5237

ISBN 0-941276-54-6

Home $|\underline{\text { What's New }}| \underline{\text { Publications }} \mid \underline{\text { Research Programs }}$ $\underline{\text { Forecasting Center }} \mid \underline{\text { About the Institute } \mid \text { Keyword Search | Using Our Site }}$ 